\title{
The Role of Chromosome Analysis in Patients with Recurrent Pregnancy Loss
}

\author{
Tekrarlayan Gebelik Kayıplı Hastalarda Kromozom Analizinin Yeri
}

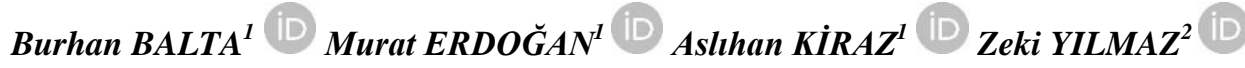

\section{$\underline{0 ̈ Z}$}

Amaç: İki ya da daha fazla klinik olarak tanımlanmış gebeliğin kaybına tekrarlayan gebelik kaybı (TGK) denir. TGK nedenleri arasında kromozom anomalileri; endokrinolojik hastalıklar; otoimmun problemler; uterin anomaliler, trombofilik faktörler yer alır. Bu çalışmada Orta Anadolu'da TGK yaşamış çiftlerin kromozom analizi sonuçları ve bunların TGK ile ilişkisini tartışmayı amaçladık.

Araçlar ve Yöntem: İki ve üzerinde düşük yapmış 721 kadın ve 699 eşi erkek toplam 1420 kişi çalışmaya dahil edildi. Kromozom analizi periferal kan lenfositleri kullanılarak standart sitogenetik Giemsa-Tripsin-Giemsa bantlama tekniği kullanılarak yapıldı. Hastaların tüm kromozomları sayısal ve yapısal kromozom anomalileri açısından incelendi.

Bulgular: 698 kişide 46,XX, 680 kişide 46,XY olmak üzere toplam 1378 kişide normal kromozom kuruluşu tespit edildi (\%97). En sik olarak 4 hastada 46,XX,9qh+(\%0.28) ve 3 hastada 46,XY,9qh+(\%0.21) olmak üzere toplam 15 hastada normal kromozom varyantları tespit edildi. Bunun yanında 12 hastada dengeli resiprokal translokasyon $(\% 0.8), 4$ hastada 45,XX,rob(13;14)(q10;q10) ve 2 hastada 45,XY,rob(13;14)(q10;q10) olmak üzere 6 hastada ise robertsoniyan translokasyon tespit edildi (\%0.4).

Sonuç: Bu çalışmada TGK' nın ebeveynlerin kromozom analizinden kaynaklanan en önemli sebebi kromozomal translokasyonlardı 18 (\%1.2). TGK yaşayan bireylerin yaklaşık \%2'sinde resiprokal ya da robertsoniyan translokasyonlar, inversiyonlar, cinsiyet kromozom anomalileri gibi sayısal ve yapısal kromozom anomalileri görülmektedir. Bu hastaların sağlıklı bebek sahibi olmaları için preimplantasyon genetik tanı testleri üreme tıbbı ile uğraşan kadın doğum uzmanı, tıbbı genetik uzmanları ve klinik embriyologlar tarafindan hastalara önerilmelidir.

Anahtar Kelimeler: kromozom analizi; preimplantasyon genetik tanı; resiprokal; tekrarlayan gebelik kaybı; translokasyon

\section{ABSTRACT}

Purpose: Recurrent pregnancy loss (RPL) is called as loss of two or more clinically defined pregnancies. The causes of RPL include chromosomal abnormalities, endocrinological disorders, autoimmune problems, uterine anomalies, and thrombophilic factors. In this study, we aimed to discuss the results of chromosomal analysis of couples who had experienced RPL in central Anatolia and their relationship with RPL.

Materials and Methods: A total of 1420 subjects, 721 females and 699 males with two or more RPL, were included in the study. Chromosome analysis was performed using standard cytogenetic GTG banding technique using peripheral blood lymphocytes. All chromosomes were examined for numerical and structural chromosomal abnormalities.

Results: Normal chromosome formation,46, XX in 698 people and 46, XY in 680 people, was detected in a total of 1378 people (97\%). Normal chromosome variant was detected in 15 patients $(1 \%)$, most commonly 46,XX,9qh+ $(0.28 \%)$ in 4 patients and $46, \mathrm{XY}, 9 \mathrm{qh}+(0.21 \%)$ in 3 patients. In addition, 12 patients had balance reciprocal translocation $(0.8 \%), 6$ patients had robertsonian translocation $(0.4 \%), 45, \mathrm{XX}$,rob $(13 ; 14)(\mathrm{q} 10 ; \mathrm{q} 10)$ in 4 patients, and 45,XY,rob(13;14)(q10;q10) in 2 patients.

Conclusion: In this study, chromosomal translocations were the most important cause of RPL in the chromosomal analysis of the parents $(\mathrm{n}=18 ; 1.2 \%)$. Approximately $2 \%$ of individuals with RPL have numerical and structural chromosomal abnormalities such as reciprocal or robertsonian translocations, inversions, and sex chromosomal abnormalities. In order to have healthy babies, preimplantation genetic diagnostic tests should be recommended to the patients by obstetricians, medical geneticists and clinical embryologists who are involved in reproductive medicine.

Key Words: chromosome analysis; preimplantation genetic testing; reciprocal; recurrent pregnancy loss; translocation

\author{
Received: 05.11.2020; Accepted: 11.12.2020 \\ ${ }^{1}$ Department of Medical Genetics, Kayseri State Hospital, Kayseri, Turkey. \\ ${ }^{2}$ Department of Obstetrics and Gynaecology, Özel Erciyes Hospital, Kayseri, Turkey. \\ Corresponding Author: Burhan BALTA, ${ }^{1}$ Department of Medical Genetics, Kayseri State Hospital, Kayseri, Turkey. e-mail: burhan0629@gmail.com
}

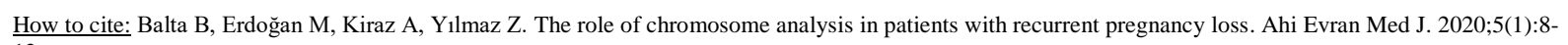
12 . 


\section{INTRODUCTION}

Recurrent pregnancy loss is an important health problem affecting women in reproductive period. According to the definition of the American Society for Reproductive Medicine, the loss of two or more clinically defined pregnancy is called recurrent pregnancy loss (RPL). Among the causes of RPL are endocrinological diseases and factors such as thyroid disease, hyperprolactinemia, diabetes mellitus (17-20\%); autoimmune problems including antiphospholipid antibody syndrome(20\%), anatomic factors including congenital or acquired uterine anomalies(10-15\%), chromosome abnormalities(2-5\%), infections $(0.5-5 \%)$ and thrombophilic factors. ${ }^{1,2}$ However, $40-50 \%$ of cases of RPL still remain unexplained. In fact, the striking inefficiency of human reproduction results from spontaneous fetal aneuploidy. Approximately, 50$70 \%$ of sporadic spontaneous losses exhibit some variety of chromosomal abnormalities, autosomal trisomies (60\%), monosomy(20\%), and polyploidy. Meiotic anomalies occur during oogenesis or spermatogenesis and usually occur in oocytes of older women. ${ }^{3}$ The relationship between advanced maternal age and chromosomal abnormalities is a well-known scientific fact. Therefore, advanced maternal age increases recurrent pregnancy loss risk, and half of the pregnancies that reach the age of 42 result in loss of pregnancy. ${ }^{4,5}$ While $75 \%$ of spontaneous miscarriages after the age of 35 years are associated with chromosomal abnormalities, this rate is around $50 \%$ in pregnancies before the age of 35 years. ${ }^{6}$

Parental chromosomal abnormalities that include balanced translocations is a remarkable cause of RPL $(2 \%-5 \%)$. Genetic changes to be detected give us important information about the frequency of recurrence of miscarriages, the chance of a healthy pregnancy and the planning of subsequent pregnancies. Unbalanced translocations are responsible for at least $1 \%$ of spontaneous miscarriages. When parents are examined, they are found to be reciprocal or Robertsonian translocation carriers. These individuals are important because of the risk of creating recurrent unbalanced gamete. In addition, some chromosomal inversions have also been associated with RPL. ${ }^{7}$
In this study, we aimed to discuss the chromosome analysis results of couples who have experienced RPL in Central Anatolia and to discuss the association of these with RPL.

\section{MATERIALS and METHODS}

We performed a cross-sectional descriptive study. A total of 1420 individuals, 721 women who had 2 or more miscarriages and 699 spouses of these women who applied to Kayseri Training and Research Hospital Medical Genetics clinic between January 2013 and November 2018 were examined retrospectively. Patients with only one pregnancy loss were excluded from the study. Age, gender, chromosome analysis results were noted retrospectively.

This study was carried out according to the Declaration of Helsinki and Good Clinical Practices Guidelines and with the 2019/65 numbered and 23.01.2019 dated approval of Erciyes University Ethics Committee. A consent form was taken from all the participants in the study.

\section{Chromosome Analysis}

Chromosome analysis was performed with patients' peripheral blood lymphocytes by using the standard cytogenetic GTG banding technique. 72 hours of culture was performed using peripheral blood lymphocytes. KaryoMAX Colcemid Solution (Gibco) was added at the 70th hour to stop the chromosomes at the metaphases stage. $0.075 \mathrm{M} \mathrm{KCl}$ was used as a hypotonic agent and the fixative formed by adding 1 part acetic acid to 3 parts methanol was used for harvesting stage. Metaphase preparations obtained after the culture were stained using the Giemsa-Trypsin-Giemsa (GTG) banding method. At least 20 metaphase areas from each patient were evaluated microscopically. If an abnormality was found in chromosome structure, up to 40 areas were examined. 10 of these were karyotyped and evaluated with Cytovision (Applied Imaging). All metaphases were examined in terms of numerical and structural chromosomal abnormalities. 


\section{Statistical Analysis}

Statistical analyses were performed using the Statistical Package for Social Sciences (SPSS. Inc.. Chicago. Illinois. USA) 23.0 for Windows. The descriptive statistics was performed. The results were given as n, percent, and mean \pm SD. The $p<0.05$ was accepted as statistically significant.

\section{RESULTS}

In this study, chromosome analysis was performed on 1420 patients who had two or more miscarriages. The average age of the women who participated in the study was $29.2 \pm 6.3$ while the average age of men was $32.4 \pm 5.7$. Normal chromosome structure was found in 1378 (97\%) participants, 46,XX was found in 698 and 46,XY was found in 680. Normal chromosome variant was detected in 15 patients (1\%), most commonly 46,XX,9qh+ $(0.28 \%)$ in 4 patients and $46, X Y, 9 q h+(0.21 \%)$ in 3 patients.

Table 1. Normal chromosome variants considered as polymorphism in chromosome analysis of 1420 male and female patients with recurrent pregnancy loss.

\begin{tabular}{lcc} 
Chromosomal Karyotype & Number & Percentage in $\mathbf{1 4 2 0}$ patients \\
\hline 46,XX,9qh+ & 4 & $\% 0.28$ \\
$46, X Y, 9 q h+$ & 3 & $\% 0.21$ \\
$46, X X, 1 q h+$ & 1 & $\% 0.07$ \\
$46, X Y, 1 q h+$ & 1 & $\% 0.07$ \\
$46, X Y, 1 q h+, 9 q h+$ & 1 & $\% 0.07$ \\
$46, X X, 13 p s t k+$ & 1 & $\% 0.07$ \\
$46, X X, 16 q h+$ & 1 & $\% 0.07$ \\
$46, X X, 21 \mathrm{ps}+$ & 1 & $\% 0.07$ \\
$46, X X, 22 p s+$ & 1 & $\% 0.07$ \\
$46, X Y$, inv(9)(p11q13) & 1 & $\% 0.07$ \\
[3]/46,XY[37] & & $1 \%$ \\
Total & 15 & \\
\hline
\end{tabular}

In addition to these, balanced reciprocal translocations were found in 12 patients $(0.8 \%)$. Robertsonian translocations were found in 6 patients $(0.4 \%)$, $45, \mathrm{XX}, \operatorname{rob}(13 ; 14)(\mathrm{q} 10 ; \mathrm{q} 10)$ in 4 patients, and $45, \mathrm{XY}, \operatorname{rob}(13 ; 14)(\mathrm{q} 10 ; \mathrm{q} 10)$ in 2 patients. A patient with $46, X X, \operatorname{inv}(3)(\mathrm{p} 21 ; \mathrm{q} 29)(0.07 \%)$ and another patient who have sex-autosome translocation 46, XX, t (X; 20) (p22.3; q11.2) were also detected. The frequency of robertsonian and reciprocal translocations, deletions and numerical chromosome anomalies in patients with recurrent pregnancy loss is approximately $2 \%$. The chromosomal rearrangements found are listed in Table 1,2 and 3 and
Figure 1 according to their numerical, structural, gender and normal chromosome variants.

When Robertsonian and reciprocal translocations are considered together, the most frequently found translocation was rob $(13 ; 14)$ in both men and women. It was found 4 times in women and 2 times in men. Among female translocation carriers, chromosome $13(n=5)$ was the most common chromosome. This was followed with chromosome 14. Among male translocation carriers, again chromosome $13 \quad(n=4)$ was the most common chromosome. This was followed with chromosome 5,10 and 14 , respectively.

Table 2. Structural chromosomal abnormalities in a series of 1420 male and female patients having had recurrent pregnancy loss.

\begin{tabular}{lcc}
\hline Chromosomal Karyotype & Number & $\begin{array}{c}\text { Percentage in 1420 } \\
\text { patients }\end{array}$ \\
\hline 45,XX,rob(13;14)(q10;q10) & 4 & $\% 0.28$ \\
45,XY,rob(13;14)(q10;q10) & 2 & $\% 0.14$ \\
46,XX,t(13;16)(q11;q12) & 1 & $\% 0.07$ \\
46,XX,t(10;19)(q23;q13.4) & 1 & $\% 0.07$ \\
46,XX,t(5;21)(q10;q10) & 1 & $\% 0.07$ \\
46,XX,t(8;15)(p11.2;q11.2) & 1 & $\% 0.07$ \\
46,XX,t(X;20)(p22.3;q11.2) & 1 & $\% 0.07$ \\
46,XY,t(1;15)(p36.3;q26.3) & 1 & $\% 0.07$ \\
46,XY,t(1;18)(q31;q23) & 1 & $\% 0.07$ \\
46,XY,t(14;18)(q13;q23) & 1 & $\% 0.07$ \\
46,XY,t(3;10)(q21;q24) & 1 & $\% 0.07$ \\
46,XY,t(5;13)(q31;q32) & 1 & $\% 0.07$ \\
46,XY,t(8;10)(q13;q11.2) & 1 & $\% 0.07$ \\
$46, X Y, t(2 ; 5)(p 11.2 ; q 35)$ & 1 & $\% 0.07$ \\
46,XY,del(18)(p11.1)[7] & 1 & $\% 0.07$ \\
/46,XY[13] & & $\% 0.07$ \\
46,XX,inv(3)(p21;q29) & 1 & $\% 1.4$ \\
Total & 20 & \\
\hline
\end{tabular}

Table 3. Numerical chromosomal abnormalities in a series of 1420 male and female patients having had recurrent pregnancy loss.

\begin{tabular}{lcc}
\hline Chromosomal Karyotype & Number & $\begin{array}{r}\text { Percentage in } \\
\mathbf{1 4 2 0} \text { patients }\end{array}$ \\
\hline $45, \mathrm{X}[2] / 46, \mathrm{XX}[38]$ & 3 & $\% 0.21$ \\
$45, \mathrm{X}[6] / 46, \mathrm{XX}[44]$ & 1 & $\% 0.07$ \\
$45, \mathrm{X}[1] / 47, \mathrm{XXX}[2] / 46, \mathrm{XX}[32]$ & 1 & $\% 0.07$ \\
$47, \mathrm{XXY}[2] / 46, \mathrm{XY}[48]$ & 1 & $\% 0.07$ \\
$47, \mathrm{XY},+21[2] / 46, \mathrm{XY}[37]$ & 1 & $\% 0.07$ \\
Toplam & 7 & $\% 0.49$ \\
\hline
\end{tabular}

\section{DISCUSSION}


The most important cause of pregnancy loss is chromosomal abnormalities. ${ }^{8}$ It is strongly associated with advanced maternal age. ${ }^{9,10}$ Especially trisomy 16 is common. These abnormalities can be detected by chorionic villus examination, amniocentesis or chromosome analysis of abortus material. However, our aim in this study was to analyse the relationship between chromosomal changes in parents and RPL and the effects of chromosomal changes on RPL.

Balanced translocations are structural chromosomal rearrangements that express the mutual exchange of parts between the two chromosomes without any significant loss of parts (Figure 2). In studies conducted, its population incidence has been reported as between 1/673 and $1 / 1000 .{ }^{11}$ In our study, the most important cause of RPL resulting from the chromosome analysis of parents was chromosomal translocations $\mathrm{n}=18(1.2 \%)$. This result was in parallel with the other studies in literature. ${ }^{12}$ Çrrakoglu et al. study showed that the most common chromosome anomaly detected in RPL patients was reciprocal translocations $(2.1 \%)^{13}$. The most common translocation was the Robertsonian translocation between Chromosomes 13 and 14, which was detected $n=6(0.4 \%)$ times. Similarly, rob(13;14) was found to be common in Tunç et al.'s and Çırakoğlu et al studies. ${ }^{13,14}$ These balanced Robertsonian translocations lead to RPL by causing monosomy 13,14 or trisomy 13,14 .

The relationship between chromosomal inversions and RPL is known. ${ }^{7,15}$ Inversions result in the formation of partial trisomy and monosomy by causing imbalance during crossing over in the course of meiosis 1 . In our study, we found pericentric inversion on chromosome 3 .

However, some chromosomal inversions such as inversion 9 have not been associated with any health problem or $\mathrm{RPL}^{16}$. 1qh+, 9qh+, 16qh+,13ps+, 13pstk+ and 22ps+ considered as normal chromosome variants are benign chromosome variants which are not associated with any health problem. ${ }^{17,18} 15(1 \%)$ normal chromosome variants were found in our study. Yildırım et al. found 3\% normal chromosome variants in their study. ${ }^{19}$ Evren study showed that chromosomal polymorphism rate was $4.8 \%$ in patients with RPL. ${ }^{20}$ In the related study, Yildırım et al. suggested that these variants might be associated with RPL. New studies are still needed on the possible effects of these variants.

Turner's syndrome is a genetic disease with 45,X karyotype, which is usually characterized by short stature, streak gonad and ovarian deficiency. ${ }^{21,22}$ Isochromosome $\mathrm{X}$, Mosaic Turner syndrome, which is a variant of Turner, causes a more moderate phenotype. These patients should be evaluated case by case and the development of internal genital organs such as uterus and ovaries and menstrual condition should be checked. Some of the Turner's syndrome patients can have pregnancy. Especially individuals with mosaic Turner syndrome have a relatively higher probability of pregnancy. Pregnancy has previously been reported in isochromosome $\mathrm{X}$ literature. However, although some of the patients have gestation, they experience problems such as pregnancy loss, gestational diabetes and cardiac anomalies. However, infants who reach the term have also been reported. ${ }^{23}$

The absence of chromosome $\mathrm{X}$ in two areas which was found in our study is an entity that can be seen in women with the advancement of age. ${ }^{24}$ The menstrual status, previous pregnancy history and healthy baby history of these cases should be investigated and they should be checked for premature ovarian deficiency. Other causes of pregnancy loss should also be kept in mind.

In our study, 1 mosaic Klinefelter syndrome was found. Healthy baby history has been reported in Klinefelter syndrome. ${ }^{25}$ In addition, there are also studies in which it was associated with RPL. ${ }^{26}$ In addition, since structural chromosomal anomalies such as chromosomal translocations and inversions cause RPL as mentioned, these couples should be evaluated in terms of preimplantation genetic tests. With developing new generation sequencing methods, preimplantation genetic test-aneuploidy(PGT-A) and structural rearrangements (PGT-SR) and unbalanced chromosomal disorders of 13 $\mathrm{MB}$ and above can be recognized reliably. ${ }^{27}$ With this method, the time to have a healthy baby is shorter and it provides great benefits to both the family and the society. 
As a conclusion, in about $2 \%$ of individuals who experience RPL, numerical and structural chromosomal anomalies such as reciprocal or Robertsonian translocations, inversions and sex chromosomal anomalies are seen. In order for these patients to have healthy babies, preimplantation genetic diagnosis tests should be recommended to the patients by obstetricians, medical geneticists and clinical embryologists dealing with reproductive medicine.

\section{Conflict of Interest}

The authors declare no conflict of interest.

\section{Acknowledgements}

We thank all the patients who participated in the study. In addition, we thank laboratory technician Mustafa Kaplan for his contributions to the documentation of patient files.

\section{REFERENCES}

1. Rajcan-Separovic E. Next generation sequencing in recurrent pregnancy loss-approaches and outcomes. Eur J Med Genet. 2019;63(2):103644.

2. Stephenson M, Kutteh W. Evaluation and management of recurrent early pregnancy loss. Clin Obstet Gynecol. 2007;50(1):132-145.

3. Webster A, Schuh M. Mechanisms of Aneuploidy in Human Eggs. Trends Cell Biol. 2017;27(1):55-68.

4. Nybo AA, Wohlfahrt J, Christens P, Olsen J, Melbye $\mathrm{M}$. Is maternal age an independent risk factor for fetal loss? West J Med. 2000;173(5):331.

5. McCallie BR, Parks JC, Trahan GD, et al Compromised global embryonic transcriptome associated with advanced maternal age. J Assist Reprod Genet. 2019;36(5):915-924.

6. Grande M, Borrell A, Garcia-Posada R, et al. The effect of maternal age on chromosomal anomaly rate and spectrum in recurrent miscarriage. Hum Reprod. 2012;27(10):3109-3117.

7. Wolf GC, Mao J, Izquierdo L, Joffe G. Paternal pericentric inversion of chromosome 4 as a cause of recurrent pregnancy loss. J Med Genet. 1994;31(2):153-155

8. Goldstein M, Svirsky R, Reches A, Yaron Y. Does the number of previous miscarriages influence the incidence of chromosomal aberrations in spontaneous pregnancy loss? J Matern Fetal Neonatal Med. 2017;30(24):2956-2960.

9. Hassold T, Hall H, Hunt P. The origin of human aneuploidy: where we have been, where we are going. Hum Mol Genet. 2007;16(R2):R203-208.

10. Nicolaidis P, Petersen MB. Origin and mechanisms of non-disjunction in human autosomal trisomies. Hum Reprod. 1998;13(2):313-319.

11. Warburton D. De novo balanced chromosome rearrangements and extra marker chromosomes identified at prenatal diagnosis: clinical significance and distribution of breakpoints. Am J Hum Genet. 1991;49(5):995-1013.

12. Goncalves RO, Santos WV, Sarno M, Cerqueira BA, Goncalves MS, Costa OL. Chromosomal abnormalities in couples with recurrent first trimester abortions. Rev Bras Ginecol Obstet. 2014;36(3):113-117.

13. Cirakoğlu A, Yılmaz Ş, Kuru D, et al. Structural Chromosomal Abnormalities in Couples with Recurrent Pregnancy Loss. Turkiye Klinikleri J Med Sci. 2010;30(4):1185-1188

14. Tunc E, Tanriverdi N, Demirhan O, Suleymanova D, Cetinel N. Chromosomal analyses of 1510 couples who have experienced recurrent spontaneous abortions. Reprod Biomed Online. 2016;32(4):414419.

15. Devine DH, Whitman-Elia G, Best RG, Edwards JG. Paternal paracentric inversion of chromosome 2: a possible association with recurrent pregnancy loss and infertility. J Assist Reprod Genet. 2000;17(5):293-296.

16. Nonaka T, Takahashi M, Nonaka C, Enomoto T, Takakuwa K. The analysis of chromosomal abnormalities in patients with recurrent pregnancy loss, focusing on the prognosis of patients with inversion of chromosome (9). Reprod Med Biol. 2019;18(3):296-301.

17. Nielsen J, Friedrich U, Hreidarsson AB. Frequency and genetic effect of 1qh plus. Humangenetik. 1974;21(2):193-196.

18. Gardner RJM, Sutherland GR, Shaffer LG. Chromosome abnormalities and genetic counseling. 4th ed. Oxford; New York: Oxford University Press; 2012.

19. Yildirim ME, Karakus S, Kurtulgan HK, Baser B, Sezgin I. The type and prevalence of chromosomal abnormalities in couples with recurrent first trimester abortions: A Turkish retrospective study. J Gynecol Obstet Hum Reprod. 2019;48(7):521-525.

20. Gümüş E. Evaluation of Chromosomal Anomalies and Polymorphisms in Primer Infertility, Azospermia and Habitual Abortion Patient Groups. Van Med J. 2019;26(1):12-17.

21. Bondy CA, Turner Syndrome Study G. Care of girls and women with Turner syndrome: a guideline of the Turner Syndrome Study Group. J Clin Endocrinol Metab. 2007;92(1):10-25.

22. Gravholt $\mathrm{CH}$. Epidemiological, endocrine and metabolic features in Turner syndrome. Eur J Endocrinol. 2004;151(6):657-687.

23. Bernard V, Donadille B, Zenaty D, et al. Spontaneous fertility and pregnancy outcomes amongst 480 women with Turner syndrome. Hum Reprod. 2016;31(4):782788.

24. Russell LM, Strike P, Browne CE, Jacobs PA. X chromosome loss and ageing. Cytogenet Genome Res. 2007;116(3):181-185.

25. Aksglaede L, Juul A. Testicular function and fertility in men with Klinefelter syndrome: a review. Eur J Endocrinol. 2013;168(4):R67-76.

26. Gruchy N, Vialard F, Decamp M, et al. Pregnancy outcomes in 188 French cases of prenatally diagnosed Klinefelter syndrome. Hum Reprod. 2011;26(9):25702575.

27. Butler R, Nakhuda G, Guimond C, et al. Analysis of PGT-M and PGT-SR outcomes at a Canadian fertility clinic. Prenat Diagn. 2019;39(10):866-870. 